\title{
ANALISA KEAMANAN INTERNET MENGGUNAKAN NESSUS DAN ETHEREAL UNIVERSITAS PUTRA INDONESIA "YPTK" PADANG
}

\author{
Rizki Nurdin ${ }^{1}$
}

\begin{abstract}
With the existence of this information will be easily obtained, the exchange of data that occurs in the virtual world will increase. In addition to the development of this technology, unwittingly evolved also crimes that occur in cyberspace that can harm users who access these sites, ranging from the delivery of viruses, spamming or other types of crime. So that institutions connected in an Internet network will be very vulnerable to network security at the institution. This is given that the productivity of an institution or company will depend on the performance of the network in it. Damage that occurs in a network will result in data exchange that occurs on the network will slow or even damage the network system. Therefore a mechanism that is used to analyze network security is required. Computer network security systems connected to the Internet must be planned and well understood in order to protect the resources within the network effectively.
\end{abstract}

Keywords : Nessus and Ethereal, Internet Security

\section{INTISARI}

Dengan adanya hal ini informasi apapun akan dengan mudah didapatkan, pertukaran data yang terjadi di dunia maya tersebut akan semakin bertambah. Di samping perkembangan teknologi ini, tanpa disadari berkembang pula kejahatan yang terjadi di dunia maya yang mampu merugikan user yang mengakses situssitus tersebut, mulai dari pengiriman virus, pengiriman spam atau jenis kejahatan lainnya. Sehingga institusi yang terhubung dalam suatu jaringan internet akan sangat rentan dengan keamanan jaringan pada institusi tersebut. Hal ini mengingat bahwa produktivitas suatu institusi atau perusahaan akan sangat bergantung pada kinerja jaringan di dalamnya. Kerusakan yang terjadi pada suatu jaringan akan mengakibatkan pertukaran data yang terjadi pada jaringan tersebut akan melambat atau bahkan merusak sistem jaringan tersebut. Oleh karena itu dibutuhkan mekanisme yang digunakan untuk menganalisa keamanan jaringan. Sistem keamanan jaringan komputer yang terhubung ke internet harus direncanakan dan dipahami dengan baik agar dapat melindungi sumber daya yang berada dalam jaringan tersebut secara efektif.

Kata Kunci: Nessus dan Ethereal, Keamanan Internet

${ }^{1}$ Dosen UPI YPTK Padang 


\section{PENDAHULUAN}

Perkembangan teknologi informasi khususnya pada World Wide Web (WWW) yaitu sistem informasi dalam bentuk teks, gambar, suara, dan lain-lain direpresentasikan dalam bentuk hypertext yang merupakan salah satu contoh nyata perkembangan teknologi informasi.

$$
\text { Perkembangan sistem }
$$

informasi saat ini sangat pesat sekali. Perkembangan ini ditandai dengan berkembangannya situssitus yang berisi informasi baik seputar ilmu pengetahuan dan teknologi, hiburan, permainan, kesehatan atupun berisi curahan hati pembuat situs.

\section{PENDEKATAN}

PEMECAHAN

\section{MASALAH}

\section{Analisis Jaringan}

Analisys merupakan tahap pertama dimana system engineering menganalisis hal-hal yang diperlukan dalam pelaksanaan proyek pembuatan atau pengembangan system dalam bidang komunikasi dan komputerisasi (Jack Febrian: 2004).

$$
\text { Secara umum dapat }
$$

dikatakan bahwa analisis jaringan digunakan untuk membantu menyelesaikan masalah-masalah yang muncul dari serangkaian pekerjaan.

Analisis jaringan ini pertama kali dikembangkan oleh perusahaan jasa konsultan manajemen Boaz, Allen dan Hamilton yang dibuat untuk keperluan perusahaan pesawat terbang lockhead. Metode yang biasanya digunakan sering disebut dengan PERT yang merupakan singkatan dari program evaluation and review tachnique. Tanpa bermaksud meniru, ada juga metode CPM (Critical Path Method) yang dapat digunakan untuk menyelesaikan masalah jaringan ini.
Perbedaan utamanya adalah, CPM lebih menekankan pada efisiensi biaya pelaksana serangkaian pekerjaan, dengan mempercepat salah satu atau beberapa kegiatan dalam rangkaian pekerjaan tersebut.

Beberapa istilah dalan analisis jaringan antara lain adalah:

1. Aktivitas, adalah suatu pekerjaan yang membutuhkan pengorbanan sumberdaya (waktu, tenaga dan biaya). Aktivitas ini biasanya disimbolkan dengan anak panah.

2. Kejadian, adalah permulaan atau akhir dari sebuah aktivitas, dan disimbolkan dengan sebuah lingkaran.

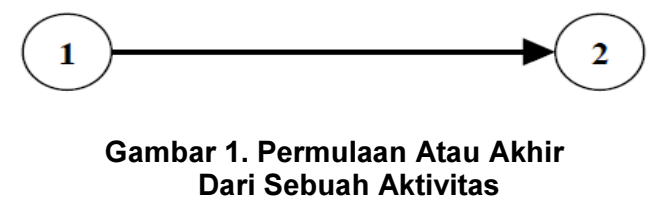

3. Jalur kritis adalah sebuah jalur yang waktu penyelesaian serangkaian pekerjaannya paling besar/panjang.

4. Earliest Start Time (ES), adalah waktu paling cepat untuk memuali sebuah aktivitas.

5. Lates Start Time (LS), adalah waktu paling lambat untuk memulai sebuah aktivitas.

6. Earliest Finish Time (EF), adalah waktu peling cepat untuk selesainya sebuah aktivitas.

7. Latest Finish Time, adalah waktu paling lambat untuk menyelesaikan sebuah aktivitas.

Beberapa Hal yang penting dalam analisis jaringan adalah:

1. Sebelum suatu aktivitas dimulai, semua aktivitas yang mendahuluinya (yang menjadi syarat) harus sudah selesai dikerjakan terlebih dahulu. 
2. Anak panah yang menjadi simbol sebuah aktivitas hanya menunjukkan arah dan uruturutan kejadian, jadi panjang pendek dan bentuknya tidak akan memberi pengaruh apapun.

3. Lingkaran, yang merupakan simbol dari kejadian, diberi nomor sedemikian rupa sehingga tidak memiliki nomor yang sama dan sebaiknya berurutan, sehingga dapat menggambarkan urutan kejadian. Biasanya nomor yang lebih kecil diletakkan di kejadian awal (permulaan anak panah).

4. Dua buah kejadian (lingkaran) hanya dapat dihubungkan dengan satu anak panah.

5. Sebuah rangkaian pekerjaan hanya dapat dimulai dan diakhiri dengan sebuah kejadian (lingkaran).

Namun demikian, seringkali suatu kasus jaringan dihadapkan pada kondisi dimana poin 4 dan 5 di atas, tidak dapat dihindari, sehingga untuk mengatasinya harus dibuatkan atau dibantu dengan sebuah aktivitas dummy.

Aktivitas dummy adalah aktivitas yang sebenarnya tidak ada, sehingga tidak memerluakan pengorbanan sumber daya. Jadi manfaat dari aktivitas dummy adalah:

a. Untuk menghindari terjadinya kondisi dimana dua kajian dihubungkan oleh lebih dari satu anak panah

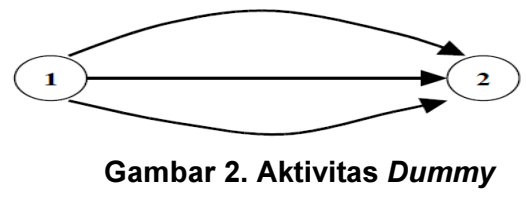

Dengan aktivitas dummy akan menjadi :

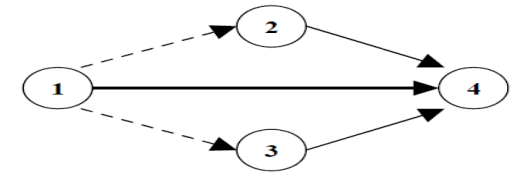

Gambar 2.3 Hasil Aktivitas Dummy

b. Untuk memenuhi ketentuan, di mana serangkaian kejadian hanya dapat dimulai dan diakhiri dengan satu kejadian (lingkaran).

c. Untuk menunjukkan urutan kejadian atau aktivitas yang sebenarnya.

\section{Konsep Keamanan Jaringan Internet}

Internet telah berkembang ke seluruh pelosok dunia secara global dan tidak mempunyai batas-batas negara lagi, kejahatan yang mungkin timbul masih tetap mempunyai ciri dan cara yang bergantung kepada negara/daerah tempat sipelaku berada, yaitu cara perpikir, cara pandang, moral, norma kehidupan dan pergaulan, bahkan bahasa pun sangat mempengaruhinya serta fakto-faktor lokal lainnya. Pintu dan tingkat kecanggihan kejahatan ditingkat global berkembang bersama perkembangan jaman dan kebudayaan lokal.

Sebagai salah satu contoh perkembangan internet, kita bisa melihat salah satunya di Jepang. Pertumbuhan pemakai internet di Jepang adalah seperti garis linier (deret hitung), naik secara pasti dari tahun ke tahun, dan ditahun 1999, telah mencapai 15 juta orang lebih, atau 1/10 jumlah penduduk Jepang. Kemudian, dilihat dari pemakaian internet untuk apa, yang terbanyak adalah untuk e-mail dan untuk mencari informasi secara gratis (masing-masing $98.5 \%$ dan 98\%). Setelah itu untuk mailing-list, belanja secara on-line lewat internet, untuk membuat homepage perusahaan ataupun pribadi, menduduki peringkat berikutnya. On-line 
shopping hanya menduduki rangking ke-4 (38.4\%), menandakan bahwa belanja lewat internet masih belum dilirik oleh kebanyakan orang, mungkin karena mereka masih raguragu tentang keamanan belanja di dunia maya (Agus Fanar Syukri: 2003).

Bahwa sebenarnya internet belumlah benar-benar aman. Ada 2 alasan utama ketidakamanan internet adalah sebagai berikut:

1. Internet adalah wilayah bebas tak bertuan, tak ada pemerintahan \& hukum yang mengaturnya. Manajemen dan perlindungan keamanan masing-masing jaringan diserahkan sepenuhnya kepada penanggungjawab jaringan (administrator jaringan internet). Dan pada kenyataannya, tidak semua administrator jaringan, mengerti dengan baik tentang keamanan internet.

2. Masih banyaknya 'hole' (lubang) di sistem komputer dan jaringan yang dapat dimanfaatkan oleh cracker demi keuntungan/kepuasan nafsu pribadinya.

Pada era global ini, keamanan sistem informasi berbasis internet harus sangat diperhatikan, karena jaringan komputer internet yang sifatnya publik dan global pada dasarnya tidak aman. Pada saat data terkirim dari suatu terminal asal menuju ke terminal tujuan dalam internet, data itu akan melewati sejumlah terminal yang lain yang berarti akan memberi kesempatan pada user internet yang lain untuk menyadap atau mengubah data tersebut. Sistem keamanan jaringan komputer yang terhubung ke internet harus direncanakan dan dipahami dengan baik agar dapat melindungi sumber daya yang berada dalam jaringan tersebut secara efektif. Apabila ingin mengamankan suatu jaringan maka harus ditentukan terlebih dahulu tingkat ancaman (threat) yang harus diatasi, dan resiko yang harus diambil maupun yang harus dihindari. Berikut ini akan dibahas mengenai ancaman (threat) , kelemahan, dan policy keamanan (security policy) jaringan.

\section{Insiden Keamanan Jaringan}

Menurut G. J. Simons,
keamanan informasi adalah
"bagaimana kita dapat mencegah
penipuan (cheating) atau paling
tidak mendeteksi adanya penipuan
disebuah system yang berbasis
informasi, dimana informasinya
sendiri tidak memiliki arti fisik.
sendiri tidak memiliki arti fisik.

Security attack, atau
serangan terhadap keamanan sistem informasi, dapat dilihat dari sudut peranan komputer atau jaringan komputer yang fungsinya adalah sebagai penyedia informasi. Menurut W. Stallings ada beberapa kemungkinan serangan (attack):

1. Interruption: Perangkat sistem menjadi rusak atau tidak tersedia. Serangan ditujukan kepada ketersediaan (availability) dari sistem. Contoh serangan adalah "denial of service attack".

2. Interception: Pihak yang tidak berwenang berhasil mengakses aset atau informasi. Contoh dari serangan ini adalah penyadapan (wiretapping).

3. Modification: Pihak yang tidak berwenang tidak saja berhasil mengakses, akan tetapi dapat juga mengubah (tamper) aset. Contoh dari serangan ini antara lain adalah mengubah isi dari website dengan pesan-pesan yang merugikan pemilik website.

4. Fabrication: Pihak yang tidak berwenang menyisipkan objek palsu ke dalam sistem. Contoh dari serangan jenis ini adalah memasukkan pesanpesan palsu 
seperti e-mail palsu ke dalam jaringan komputer.

Insiden keamanan jaringan adalah suatu aktivitas terhadap suatu jaringan komputer yang memberikan dampak terhadap keamanan sistem yang secara langsung atau tidak bertentangan dengan security policy sistem tersebut. Secara garis besar, insiden dapat diklasifikasikan menjadi: probe, scan, account compromize, root compromize, packet sniffer, denial of service, exploitation of trust, malicious code, dan infrastructure attacks. Berikut ini akan dibahas mengenai jenis jenis insiden tersebut

\section{Nessus}

Sekarang sudah bisa diketahui beberapa jenis serangan dan gangguan kejahatan yang terjadi di dalam jaringan komputer perusahaan, dan beberapa metode umum yang sering dilakukan untuk menyerang IT aset anda. Hal ini sangat penting untuk dipelajari karena nessus perlu disesuaikan dengan kondisi infrastruktur jaringan yang ada di perusahaan dan model bisnis dengan asset teknologi informasi. Cara cepat untuk menentukan apakah dibutuhkan nessus adalah dengan menjawab beberapa pertanyaan berikut ini.

1. Apakah anda memiliki data, yang jika berada ditangan orang lain akan berakibat fatal, dapat mengakibatkan mimpi buruk bagi citra perusahaan atau data finansial mengenai keuntungan dan kerugian costumer dan clients.

2. Apakah anda memiliki data jika data itu dicuri dapat melumpuhkan operasi anda dan kredibilitas perusahaan anda.

\section{Ethereal}

Penganalisa dengan ethereal merupakan pendeteksi lalu lintas jaringan dengan men-capture paket dalam jaringan secara langsung dan menayangkan isi dari paket tersebut. Dimulai dengan instal paket ethereal dari repositori "universe" dan pilih applications -> internet -> ethereal.

Ethereal adalah sebuah network protocol analyzer yang dapat didapatkan secara gratis. Ethereal dapat berjalan pada sistem operasi linux dan window. Ethereal memberikan ringkasan dan informasi yang mendetail mengenai paket yang "ditangkap".

Berikut ini adalah fitur-fitur yang dimiliki oleh ethereal-0.9.14:

1. Data dapat langsung ditangkap dari koneksi jaringan secara langsung.

2. Ethereal dapat membaca file-file yang ditangkap oleh tcpdump, NAl's Sniffer, Sniffer Pro, Sunsnoop, atmsnoop, dan lainlain.

3. Data langsung dapat dibaca dari Ethernet, FDDI , PPP, Token Ring, IEEE 802.11, classical IP over ATM, dan loopback interface.

4. Data yang ditangkap dapat dilihat secara grafis.

5. 393 protocol dapat dikenali oleh ethereal.

6. Output dapat disimpan atau diprint sebagai plain text atau sebagai Post Script.

\section{a. Prinsip Kerja Ethereal}

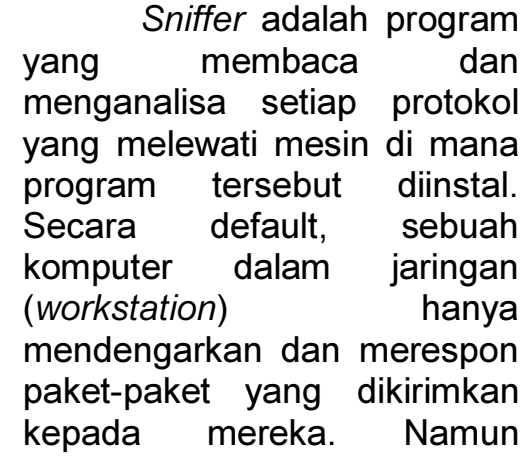


demikian, kartu jaringan (network card) dapat diset oleh beberapa program tertentu, sehingga dapat memonitor dan menangkap semua lalu lintas jaringan yang lewat tanpa peduli kepada siapa paket tersebut dikirimkan. Aktifitasnya biasa disebut dengan sniffing. Untuk dapat membaca dan menganalisa setiap protokol yang melewati mesin, diperlukan program yang bisa membelokkan paket ke komputer attaker. Biasa disebut serangan spoofing. Attaker akan bertindak sebagai Man-In-the-Middle (MIM).

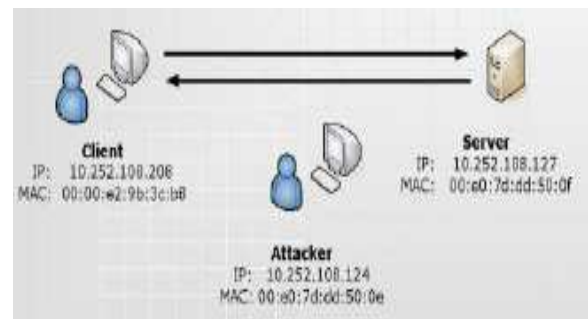

Gambar 2.5 Koneksi Tcp Sebelum Spoofing

Gambar di atas mengilustrasikan koneksi TCP yang sebenarnya, tanpa ada sebuah host yang bertindak sebagai MIM. Kemudian host attacker menjalankan program spoofing, berarti host attacker akan bertindak sebagai host yang dilewati data antara host client dan host server.

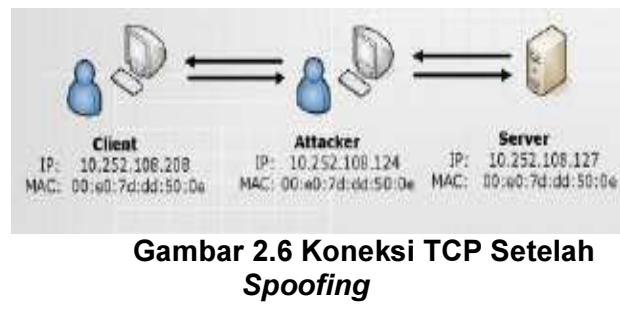

Setelah host attacker menjadi host yang berada di tengah-tengah dari dua host yang saling berkomunikasi, kemudian attacker melakukan analisa traffic dengan menjalankan program ethereal. Dengan menganalisa traffic TCP yang sudah tercapture, attacker dapat mengetahui apa saja yang dilakukan oleh host client terhadap host server.

\section{b. Arsitektur Sistem Ethereal}

Dua puluh user dalam waktu yang relatif bersamaan dengan menggunakan browser Internet Explorer 6.0 mengakses alamat http://192.168.1.1 (url server web). Seluruh user dikondisikan tidak melakukan aktivitas lain selain mengakses alamat http://192.168.1.1. Paket data dan bandwidth jaringan yang berhasil direkam oleh ethereal terlihat pada gambar 10 dan Gambar 11. Terlihat pada gambar $10 \mathrm{di}$ atas bahwa rata-rata bandwidth LAN yang terpakai sekitar 3 kbps.

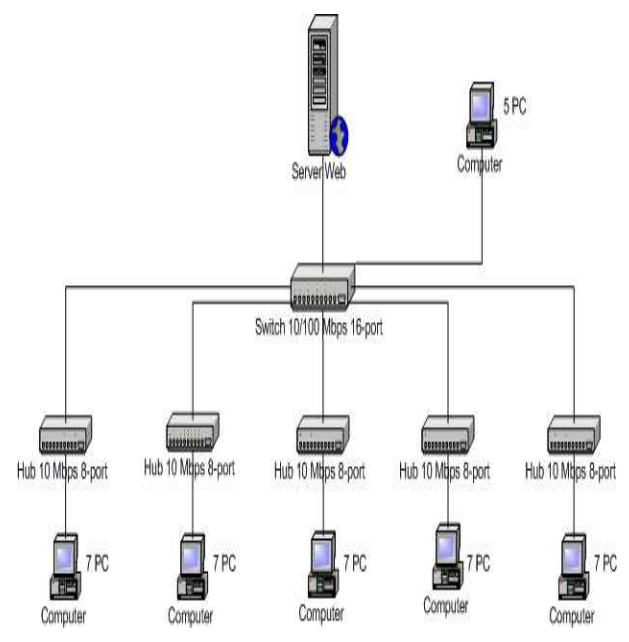

Gambar 2.8 Struktur LAN Uji Coba Menggunakan Ethereal

Komputer server web yang menjalankan aplikasi terhubung secara local area network (LAN) dengan empat 
puluh komputer user melalui switch 10/100 Mbps, seperti terlihat pada gambar 2.8. Setting IP (Internet Protocol) Address untuk komputer server web dalam pengujian ini adalah 192.168.1.1 atau http://lab.igm.ac.id, sedangkan halaman web default.htm yang nanti akan diakses oleh pengguna diletakkan pada direktori lexplorer.

\section{ANALISA NESSUS DAN ETHEREAL}

Nessus merupakan salah satu software favorit yang digunakan untuk memproteksi network dari serangan hacker. Proteksi tambahan ini cukup memadai untuk menghindari serangan hacker pada umumnya.

Sebagai software open source untuk perlindungan gangguan yang lumayan populer dan tersedia gratis. Nessus hadir untuk melindungi jaringan-jaringan dengan cara mendeteksi dan mencegah gangguan. Nessus adalah sebuah program yang berfungsi sebagai security scanner yang akan mengaudit jaringan yang dituju lalu menentukan kelemahankelemahan dari jaringan yang dituju.

Nessus merupakan suatu software yang berfungsi sebagai vulnerability scanner dan sudah digunakan oleh 75,000 organisasi / perusahaan di seluruh dunia. Pengertian Vulnerability scanner disini adalah kemampuan dari software ini untuk melihat celah keamanan (security hole) pada suatu sistem baik yang terkait dengan sistem operasi maupun aplikasi yang terpasang pada suatu sistem.

Projek "Nessus" diawali oleh Renaud Deraison pada tahun 1998 dengan tujuan menyediakan software untuk melakukan pengecekan keamanan / security audit pada suatu sistem dimana software ini bersifat remote, free, powerful, up-to-date dan mudah untuk digunakan.

\section{Lisensi :}

1. Free. Update database terbaru akan diberikan 1 minggu setelah security hole terbaru ditemukan.

2. Komersil. Update database terbaru akan diberikan sesegera mungkin setelah security hole terbaru ditemukan. Adanya support untuk troubleshooting dari produk ini dan lain sebagainya.

Nessus dapat dijalankan pada sistem operasi :

1. Linux : Fedora FC4 \& 5, Red Hat Enterprise 3 \& 4, SUSE 9.3 \& 10, Debian 3.1 (i386).

2. FreeBSD : FreeBSD $5 \& 6$ (i386).

3. Solaris : Solaris $9 \& 10$ (sparc).

4. Mac OS X: Mac OS X 10.4 (intel \& ppc).

5. Windows : Windows 2000, XP and 2003 (32 bits).

\section{Installasi}

Instalasi software di tutorial ini dijalankan pada Microsoft Windows. Download software berikut: Nessus http://www.nessus.org/download/.

1. Double klik pada software yang di download.

2. Step 1.

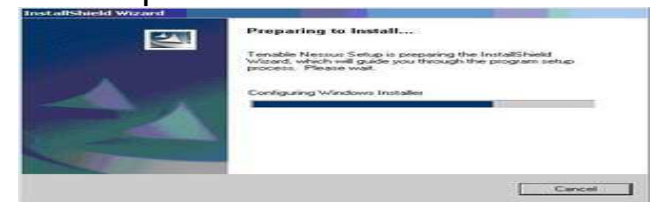

3. Step 2.

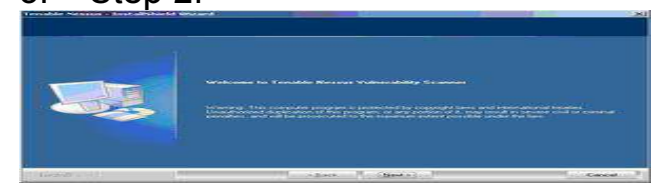




\section{Step 3}

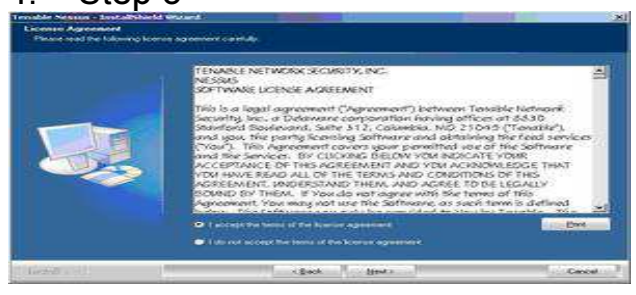

\section{Step 4.}

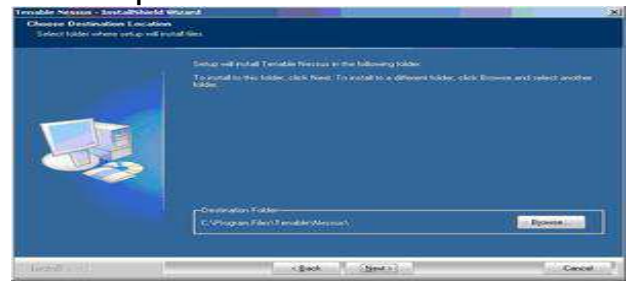

\section{Step 5.}

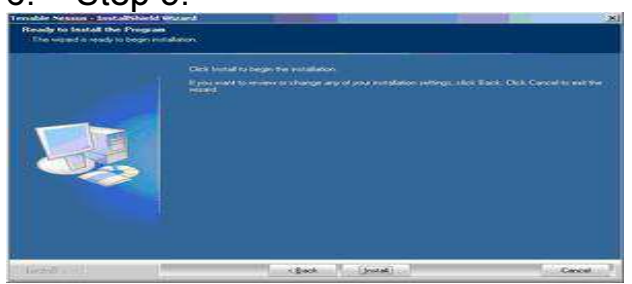

7. Step 6 (Registrasi software). Registrasi software ini dibutuhkan untuk update database Nessus. Dapat dilakukan sebelum atau sesudah instalasi software.

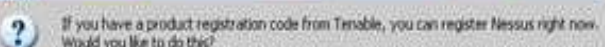

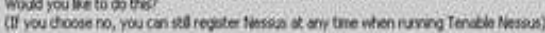

\section{\begin{tabular}{|l|l|}
\hline Nos: No \\
\hline
\end{tabular}}

\section{Step 7 (Instalasi Plugins)}

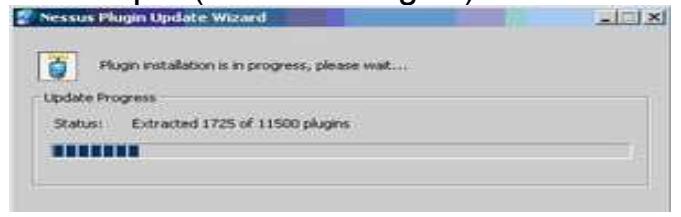

9. Step 8 (Finish).

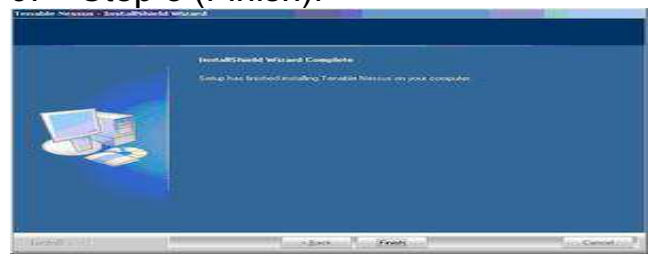

\section{Nessus Client \& Reporting} http://www.pss.intekras.com/tools/ne ssj/\#download.

1. Unzip file nessj-0.7.0-win.zip ke folder / direktori yang telah ditentukan. Contoh : C:Inessj.

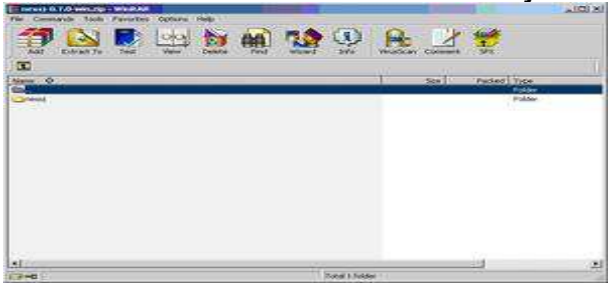

2. Hasil unzip : c:Inessj (perhatikan nessg.exe).

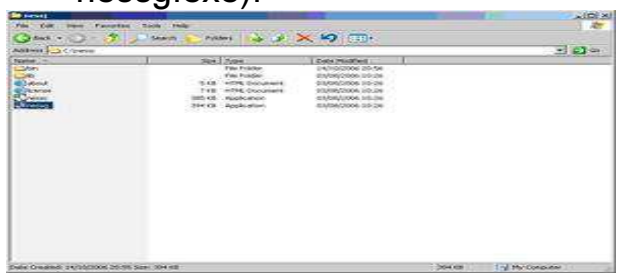

\section{Pemakaian Nessus}

Dalam melakukan scanning, Nessus dapat langsung dijalankan pada server / host yang telah terinstall software Nessus atau dapat pula scanning secara remote menggunakan Nessus Client. Pada Tutorial ini akan ditekankan kegiatan scanning secara remote ke Nessus Server. Sebelum menjalankan Nessus Server pastikan terlebih dahulu Nessus sudah di registrasi. Jalankan Product registration apabila belum dilakukan.

Start $\longrightarrow$ Programs $\longrightarrow$ Tenable Network Security $\longrightarrow$ Nessus $\longrightarrow$ Product Registration.

Masukkan code aktifasi
apabila sudah mendaftar
sebelumnya. Apabila ingin membuat
code aktifasi, daftarkan ke
http://www.nessus.org/register.




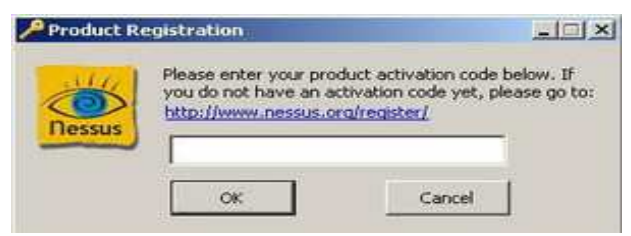

Langkah selanjutnya adalah membuat User yang akan digunakan untuk login ke Nessus Server secara remote menggunakan Nessus Client.

Start $\longrightarrow$ Programs $\longrightarrow$ Tenable Network Security $\longrightarrow$ Nessus $\longrightarrow$ User Management.

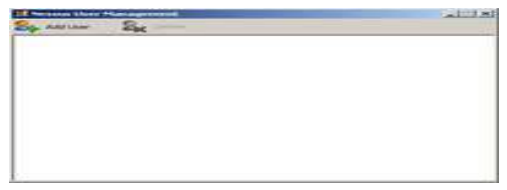

Membuat User Nessus.

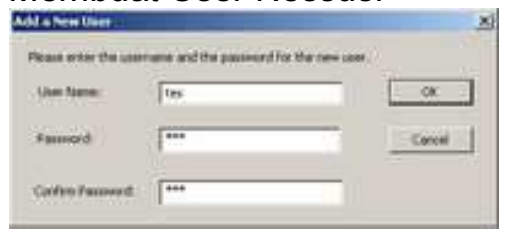

User Nessus telah dibuat.

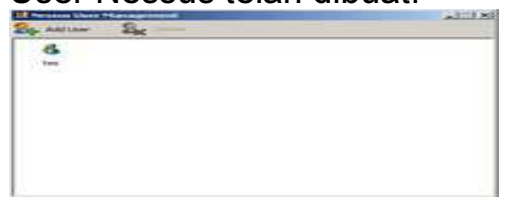

Menjalankan Nessus Server :

Start $\rightarrow$ Programs $\rightarrow$ Tenable Network Security $\longrightarrow$ Nessus $\longrightarrow$ Tenable Nessus.

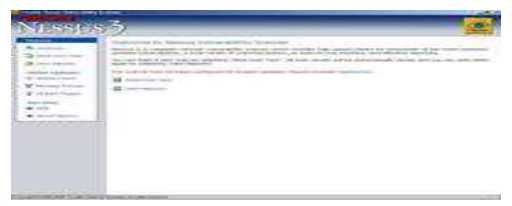

Akses ke Nessus Server menggunakan Nessus Client (NESSG.EXE) :

Jalankan / double klik nessg.exe.
Protocol : TLSv1

Server : Ip address dari Nessus Server

Port : Port dari Nessus Server (default 1241)

User : someuser

Password : somepassword

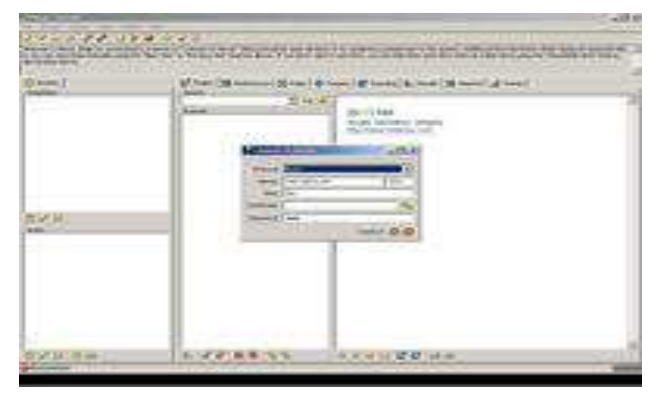

Tampilan Nessus Client saat pertama kali running. Klik Ok untuk menerima key certificate.

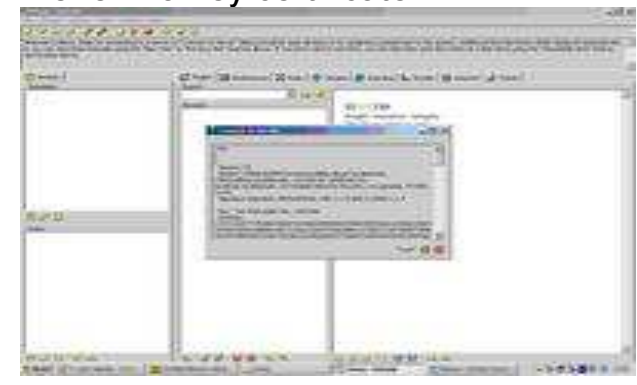

Tampilan Plugins yang terpasang pada Nessus Client (Kolom Plugins).

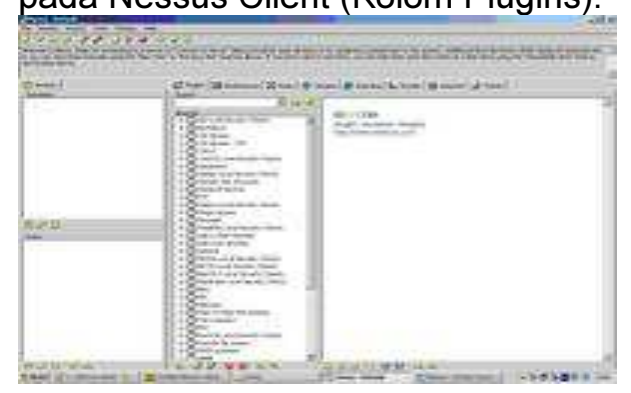

Agar Nessus Client dapat memberikan informasi yang dibutuhkan setelah melakukan scanning, maka plugins ini perlu diaktifkan sebelum proses scanning dilaksanakan. 


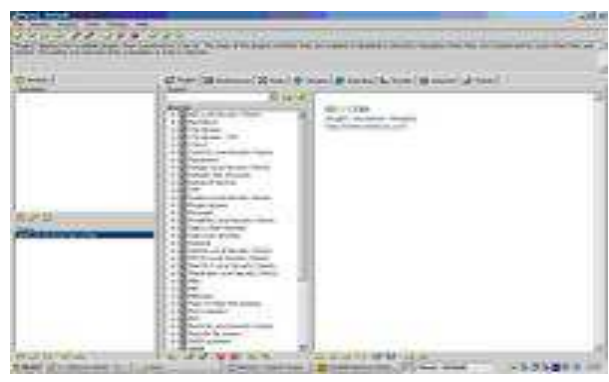

Proses scanning dilakukan dengan memasukkan ip address / range ip address dari target yang akan di scan (Kolom Targets). Contoh: sebuah virus dengan ip address 152.102.20.5

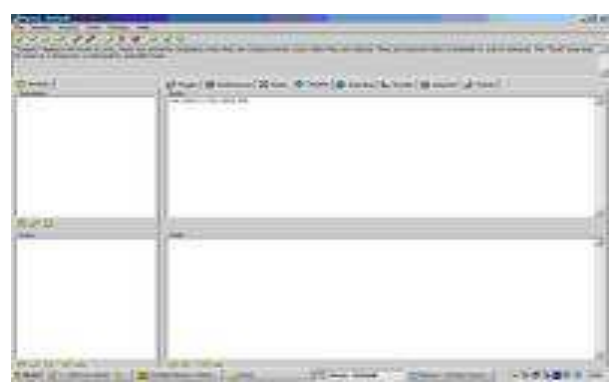

Setelah ip address / range ip address dimasukkan, lakukan proses scanning (Kolom Scanning).

Action $\longrightarrow$ Start Scan atau dengan kombinasi tombol Ctrl + Shift $+R$.

Proses scanning berjalan.

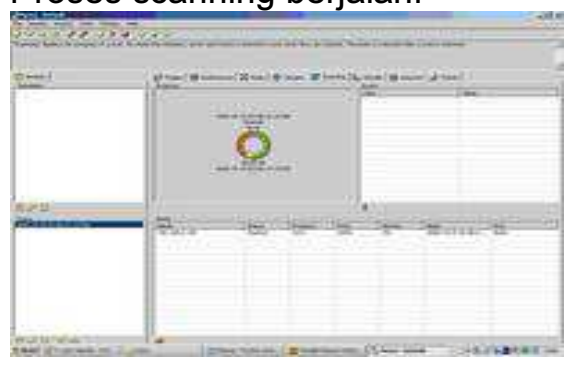

Proses scanning selesai.

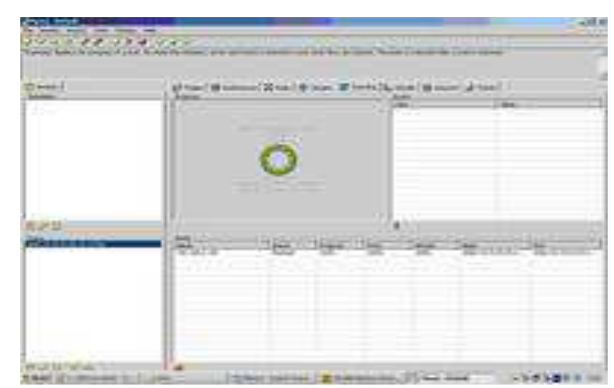

Hasil scanning menggunakan Nessus Client (Kolom Result).Kolom disebelah kanan memberikan informasi detail mengenai security hole / lubang keamanan yang ditemukan dan langkah-langkah yang perlu dilakukan untuk menutup security hole tersebut. Hacker dapat memanfaatkan informasi dari Nessus ini untuk melakukan penyerangan ke sistem yang memiliki security hole.

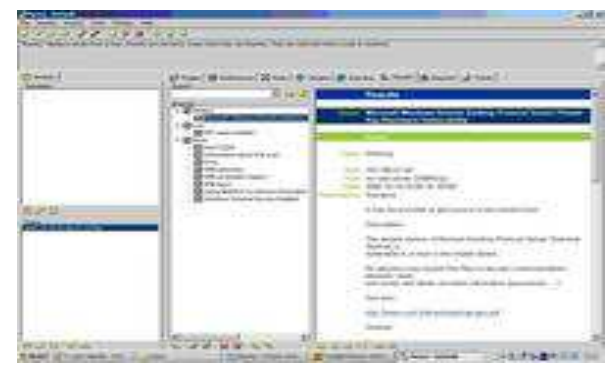

Hasil dari scanning dapat dibuat menjadi suatu report dan diexport ke *.html atau *.xml (Kolom Report).

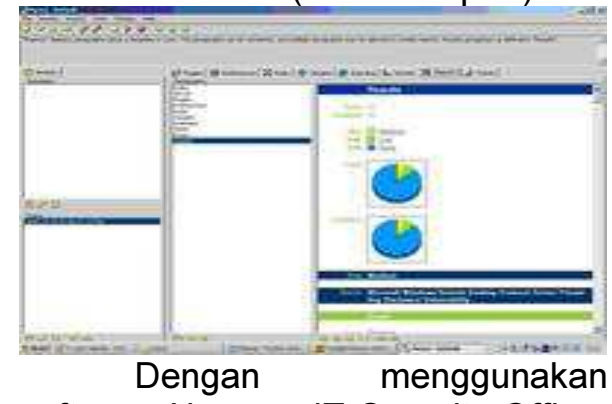

software Nessus, IT Security Officer dapat melakukan audit terhadap sistem yang mereka miliki dan memberikan gambaran mengenai langkah-langkah yang perlu dilakukan untuk mengamankan sistem mereka. 


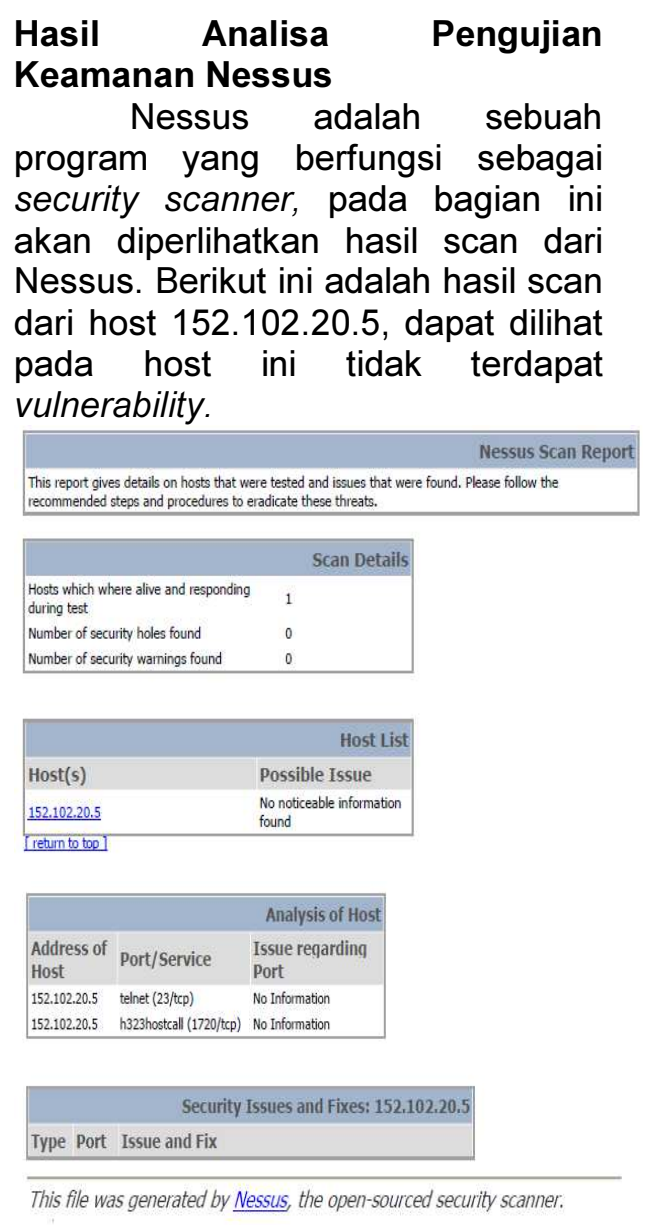

Berikut ini akan diperlihatkan sebuah contoh dari host, yaitu host dengan IP 152.102.20.5, yang memiliki vulnerabiliity pada port 80 :

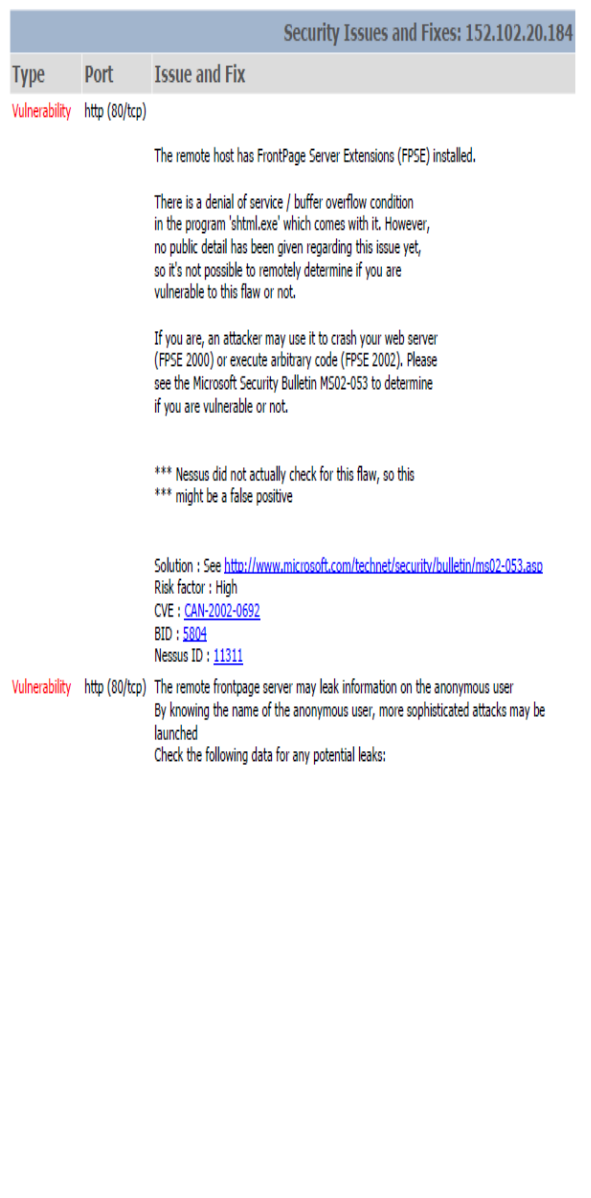




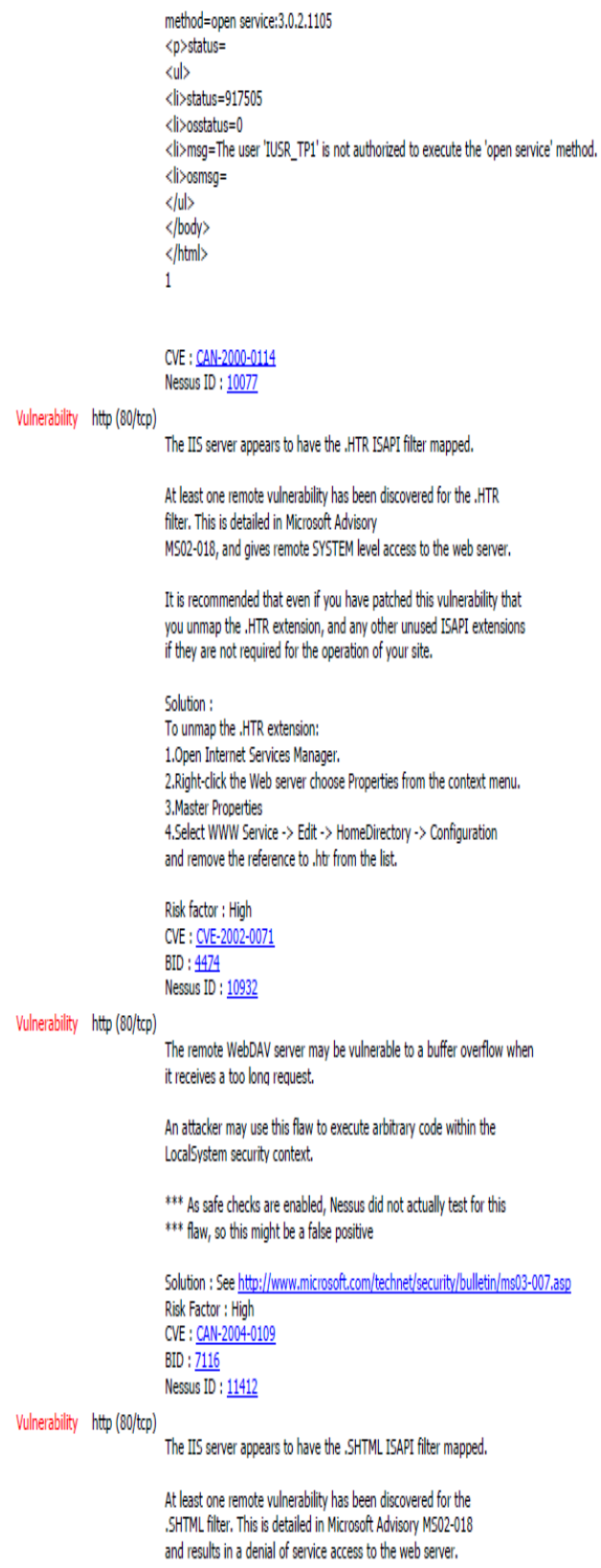

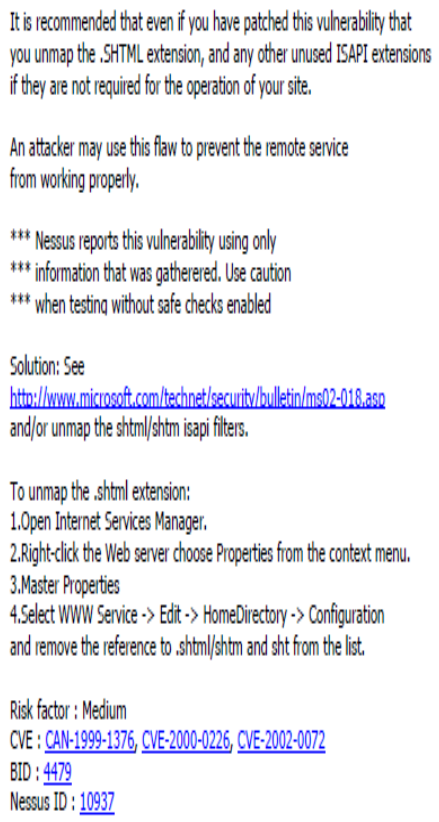

Penjelasan dari hasil report mengenai vulnerability di atas akan diuraikan di bawah ini:

a. Host dengan IP152.102.20.5 memiliki Front Page Server Extension (FPS) yang terinstal di dalamnya, yang dapat menyebabkan denial of service(DOS)/buffer overflow di dalam program shtml.exe.

b. Frontpage server pada host dengan IP 152.102.20.5 sangat mungkin untuk membocorkan informasi pada anonymous user, yang dapat menyebabkan serangan yang membahayakan host.

c. IIS server pada host dengan IP 152.102.20.5 mempunyai .HTR ISAPI filter mapped. Sedikitnya ada sebuah vulnerability yang disebabkan oleh .HTR filter. Hal ini dapat diatasi dengan cara melakukan unmap pada extension pada HTR. Server ini juga mungkin mempunyai .SHTML ISAPI filter mapped. Sama seperti .HTR, sedikitnya ada sebuah vulnerability yang disebabkan oleh SHTML filter. 
d. WebDAV server mungkin mempunyai vulnerability ketika menerima request yang terlalu panjang.

\section{Instalasi Ethereal}

Ethereal adalah sebuah protokol analyzer jaringan yang free, yang berjalan pada sistem operasi Windows, Linux/Unix dan komputer Mac. Ethereal mampu menganalisa lebih dari 500 protokol.

Untuk instalasi Ethereal, Anda perlu memiliki akses ke komputer yang mendukung Ethereal dan packet capture library libpcap. Jika libpcap belum diinstal, Anda perlu meng-instalnya sebelum menggunakan Ethereal.

Donwload dan instal Ethereal dan (jika perlu) software libpcap. Jika perlu, download dan instal software libpcap. Pointer ke software libpcap disediakan dari halaman download Ethereal. Untuk mesin Windows, software libpcap dikenal sebagai WinPCap dan dapat ditemukana di http://winpcap.polito.it. Pergi ke http://www.ethereal.com dan download dan instal binary Ethereal untuk komputerAnda.

\section{Hasil Analisa Pengujian Keamanan Ethereal \\ Seperti yang telah} disebutkan di atas bahwa ethereal berfungsi untuk menangkap paket data langsung dari jaringan, dan juga memberikan informasi mengenai paket data yang ditangkap. Berikut ini akan diperlihatkan hasil capture dari ethereal.

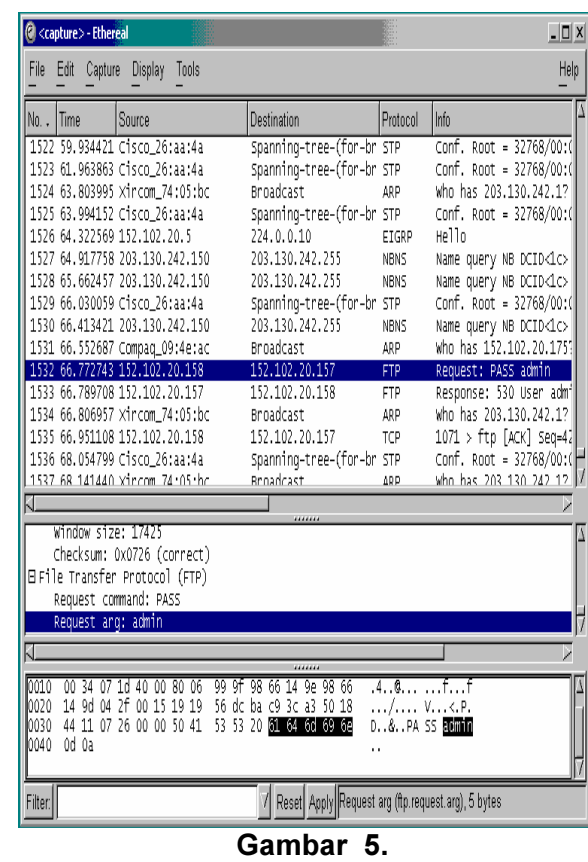

Pada tampilan di atas dapat dilihat bahwa dengan menggunakan ethereal dapat diketahui password yang dalam contoh ini untuk mendapatkan akses mengadakan FTP session dengan 152.102.20.157. Dari contoh di bawah ini dapat dilihat bahwa host 152.102.20.189 sedang melakukan scanning terhadap host 152.102.20.158.19.2.

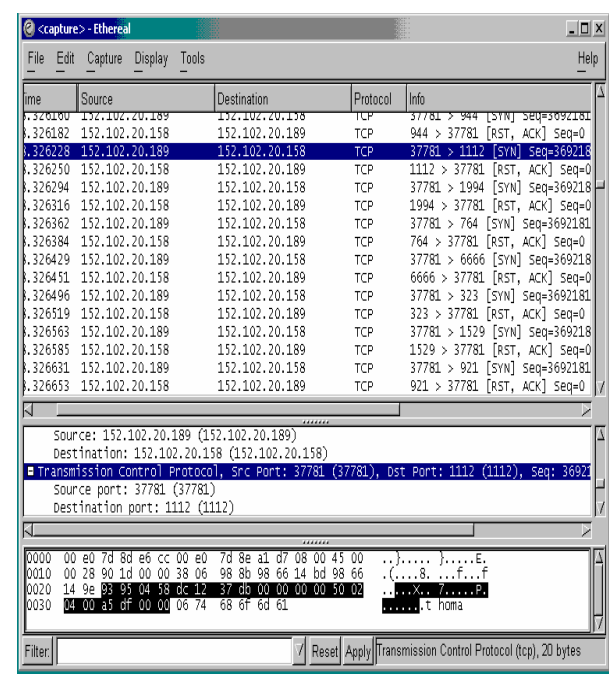

Gambar 5.1.2 
Dari hasil-hasil capture di atas dapat terlihat bahwa output dari ethereal terbagi atas tiga bagian, yaitu:

1. Bagian pertama menampilkan keseluruhan paket data yang ditangkap oleh ethereal, bagian ini memberikan informasi mengenai waktu ditangkapnya paket data oleh ethereal setelah program ethereal dijalankan, asal paket data berasal, tujuan dari paket data, protokol yang dipergunakan, dan memberikan informasi paket data yang ditanglap secara umum.

2. Bagian kedua menampilkan informasi dari paket data secara lebih mendetail.

3. Bagian ketiga menampilkan nilai heksa dari paket data yang ditangkap.

\section{KESIMPULAN}

Nessus adalah sebuah program yang berfungsi sebagai security scanner yang akan mengaudit jaringan yang dituju lalu menentukan kelemahan-kelemahan dari jaringan yang dituju.

Nessus berjalan dengan mengambil sistem informasi dan menganalisanya untuk memeriksa sesuatu yang tidak biasa/lazim terhadap suatu event yang terjadi diserver/jaringan. Ada beberapa cara bagaimana nessus bekerja. Cara yang paling populer adalah dengan menggunakan pendeteksi berbasis signature (seperti halnya yang dilakukan oleh beberapa anti virus), yang melibatkan pencocokan lalu lintas jaringan dengan basis data yang berisi cara-cara serangan dan penyusupan yang sering dilakukan oleh penyerang.

Teknik lain yang digunakan adalah dengan memantau berkasberkas sistem operasi, yakni dengan cara melihat apakah ada percobaan untuk mengubah beberapa sistem operasi utama berkas log. Teknik ini sering diimplementasikan didalam nessus, selain tentunya melakukan pemindaian terhadap log sistem untuk memantau apakah terjadi kejadian yang tidak biasa

Kelebihan nessus yang menonjol adalah plugin-based, artinya nessus memiliki plugin (modul) yang digunakan untuk proses scan dan plugin-plugin ini dapat dibuat sendiri bagi yang ingin dengan menggunakan bahasa pemrograman $\mathrm{C}$ atau dengan NASL (Nessus Scripting Language). Selain dengan jalan membuat sendiri, nessus juga menyediakan plugin online yang secara rutin diupdate dan biasa didownload dengan aplikasi 'nessus-update-plugins' yang menyatu dengan source program nessus

Kelemahan nessus adalah apabila penyusup masuk ke jaringan, nessus tidak bisa mengaktifkan alarm secara otomatis sehingga user tidak mengetahui apabila ada penyusup masuk kejaringan internet.

Ethereal adalah sebuah network protocol analyzer yang dapat didapatkan secara gratis. Ethereal dapat berjalan pada sistem operasi linux dan window. Ethereal memberikan ringkasan dan informasi yang mendetail mengenai paket yang "ditangkap". Penganalisa dengan ethereal merupakan pendeteksi lalu lintas jaringan dengan men-capture paket dalam jaringan secara langsung dan menayangkan isi dari paket tersebut. Kelebihan dari ethereal adalah data dapat langsung ditangkap dari koneksi jaringan secara langsung, ethereal dapat membaca file-file yang ditangkap oleh tcpdump, NAl's Sniffer, Sniffer Pro, Sunsnoop, atmsnoop, dan lainlain, 393 protocol dapat dikenali oleh ethereal, dan output dapat disimpan atau diprint sebagai plain text. 


\begin{abstract}
Kelemahan dari ethereal adalah open source ini hanya sekedar memantau lalu lintas jaringan internet saja dan apabila penyusup masuk ethereal tidak bisa melakukan pemblokiran penyusup tersebut.
\end{abstract}

\section{DAFTAR PUSTAKA}

[1] A.S, Rosa dan M. Shalahuddin. 2013. "Rekayasa Perangkat Lunak". Informatika: Bandung.

[2] Haviluddin. 2011. Memahami Penggunaan UML (Unified Modelling Language). Jurnal Informatika Mulawarman Vol 6 No. 1

[3] Jakimi, A. dan Koutbi, M. 2009. "An Object Oriented Approach to UML Scenarios Engineering and Code Generation". International Journal of Computer Theory and Engineering, Vol. 1, No. 1,1793-8201.

[4] Kaur, A. 2012 Application of UML in RealTime Embedded Systems. International Journal of Software Engineering \& Applications (IJSEA), Vol.3, No.2.

[5] Kyung, S. J. dan Jung, W. W. 2014. "Development of ObjectOriented Analysis and Design Methodology for Secure Web Applications". International Journal of Security and ItsApplications Vol.8, No.1
[6] Lee, S. 2012." Unified Modeling Language (UML) for Database Systems and Computer Applications", International Journal of Database Theory and Application Vol. 5, No. 1.

[7] Sathiyaraj, R., Yadav, N.S., Prabhakar, M. 2012. "Modeling Real Time Scheduler in OOAD Using UML", International Journal Of Research In Educational Methodology. Council For Innovative Research Vol.2, No.1 : ISSN:2278-7690 